\title{
Anilisis Yuridis Ruang Lingkup Antropologi Hukum Dan Dinamika
}

\author{
Dicky Candra \\ Email: dickyiembell21@gmail.com \\ No Bp: 210003600218 \\ Universitas Ekasakti Padang
}

\section{A. PENDAHULUAN}

Antropologi secara etimologis berasal dari bahasa Yunani. Kata Anthropos berartimansia dan logos berarti ilmu pengetahuan. Jadi, antropologi adalah ilmu yang mempelajari manusia. Oleh karena itu antropologi di dasarkan pada kemajuan yang telah dicapai ilmu pengetahuna sebelumnya. Pitirim Sorokim mengatakan bahwa Sosiologi adalah suatu ilmu yang mempelajari hubungan dan pengaruh timbal balik antara aneka macam gejala-gejala sosial (gejala ekonomi dengan agama, keluarga dengan moral, hukum dengan ekonomi) dengan gejala lainnya (nonsosial). Berbeda dengan pendapat Rouceke dan Warren yang mengatakan bahwa Sosiologi adalah ilmu yang mempelajari hubungan manusia dengan kelompok-kelompok. Berdasarkan uraian di tersebut, maka Sosiologi adalah jelas merupakan ilmu sosial yang objeknya adalah masyarakat sebagai ilmu. Ia berdiri sendiri karena telah memiliki unsur ilmu pengetahuan. Dalam ilmu antropologi hukum dipelajari juga mengenai Peran, Status atau kedudukan, Nilai, Norma dan juga Budaya atau kebudayaan. Kesemuanya ini merupakan hal-hal yang sangat erat kaitannya dengan ilmu antropologi hukum.

Secara historis, antropologi berkembang dari suatu deskripsi hasil-hasil laporan perjalanan para penjelajah dan penjajah tentang kehidupan manusia di daerah yang disinggahi para penjelajah, atau kehidupan salah satu suku bangsa yang tinggal di daerah jajahan. Deskripsi tersebut dikenal dengan nama etnografi. Dalam perjalanannya kemudian, antropologi berkembang sebagaimana keberadaannya sekarang baik di negara-negara Eropa Barat, Amerika maupun di Asia. Beberapa cabang antropologi yang dikenal secara luas saat ini adalah antropologi fisik atau biologi, antropologi sosial, dan antropologi budaya. Di sisi yang lain, 
antropologi juga merupakan bidang ilmu terapan sehingga hasil kajiannya dapat dimanfaatkan sebagai masukan dalam pengambilan keputusan untuk keperluan pembangunan, terutamadalam pembangunan sosial budaya, seperti antropologi pembangunan, antropologi kesehatan, antropologi ekonomi, dan sebagainya. Adapun hal hal yang akan dibahas pada makalah ini adalah bagaimana kita mengetahui manfaat - manfaat apa saja yang terkandung di dalam Ruang lingkup antropologi hukum.

\section{B. PEMBAHASAN}

\section{Ruang Lingkup Antropologi Hukum}

Antropologi merupakan disiplin ilmu yang sangat luas, karena gabungan dari humaniora, sosial dan ilmu pengetahuan untuk menjelaskan tentang manusia. Ilmu antropologi ini dibangun berdasarkan pengetahuan dari ilmu alam, termasuk asal-usul dan evolusi homo sapiens, ciri-ciri fisik manusia, perilaku manusia dan variasi di antara berbagai kelompok manusia, cara masa lalu evolusi homo sapiens mempengaruhi budaya sosial dan kelompok. Selain itu, antropologi juga dibangun berdasarkan ilmu-ilmu sosial yang mempelajari tentang hubungan manusia sosial dan budaya, sistem keturunan dan hubungan kekerabatan, spiritualitas dan religi, lembaga, konflik sosial, dan lainnya. Antropologi pertama kali berasal dari Yunani klasik dan Persia yang mempelajari dan mencoba memahami Keberagaman budaya. Sekarang ini, antropologi telah menjadi sentral dalam pengembangan beberapa bidang interdisipliner baru, seperti ilmu kognitif, studi globalisasi, genetik, dan berbagai penelitian etnis. ilmu yang mempelajari tentang manusia ini memiliki beberapa ruang lingkup antropologi yaitu :

\section{Antropologi fisik atau biologi}

antropologi fisik atau biologi ini mempelajari manusia sebagai organisme biologi yang melacak perkembangan manusia berdasarkan evolusinya dan variasi biologisnya dalam berbagai spesies. Para ahli antropologi fisik telah berusaha melacak nenek moyang jenis manusia untuk mengetahui proses, waktu dan awal mula semua orang menjadi makhluk sosial seperti sekarang. 
Mereka melacaknya melalui analisis mendalam terhadap fossil-fossil dan mengamati primata yang pernah hidup.

\section{Budaya dan Kebudayaan}

Kebudayaan hukum adalah kekuasaan yang digunakan oleh penguasa untuk mengaturmasyarakat agar tidak melanggar kaidah-kaidah sosial yang telah ada dalam masyarakat. Hukum diperlukan meski telah ada kaidah atau norma dalam masyarakat, agar terdapat keteraturan dalam kehidupan manusia melalui hukum tertulis dengan sanksi yang nyata disamping norma dan kaidah yang sanksinya lebih bersifat sosial atau akhirat. Sebagai Ilmu Pengetahuan, Antropologi Hukum dicirikan oleh 3 (tiga) hal yaitu adanya: Objek, Metode, dan Sistem Antropologi Hukum sebagai ilmu pengetahuan yang merupakan spesialisasi dari Antropologi budaya, memiliki karakter :

$>$ Antropologi Hukum, adalah Ilmu pengetahuan (logos) tentang Manusia (antropos) yang berhubungan dengan Hukum.

$>$ Manusia, adalah manusia yang hidup bermasyrakat, masyarakat yang masih sederhana budayanya (primitif) dan yang sudah Maju (modern).

$>$ Budaya adalah budaya Hukum, yaitu segala bentuk perilaku budaya manusia yang mempengaruhi masalah hukum budaya adalah milik bersama yang perlu dipertahankan atau dilestarikan. Budaya hukum adalah tanggapan masyarakat terhadap suatu perbuatan yang dianggap baik, yang hal ini juga bergantung pada sikap penegak hukum. Nilai budaya atau Postulat adalah nilai yang ada dalam masyarakat modern dan masyarakat sederhana yang dinilai baik atau dipertahankan.

\section{Antropologi psikologis}

Antropologi psikologi adalah cabang dari antropologi yang bersifat interdisipliner dan mengkaji interaksi kebudayaan dan proses mental. Cabang ini terutama memperhatikan cara perkembangan manusia dan enkulturasi dalam kelompok budaya tertentu-dengan sejarah, bahasa, 
praktik, dan kategori konseptualnya sendiri-membentuk proses perolehan kognisi, emosi, persepsi, motivasi, dan kesehatan mental. Juga memeriksa tentang bagaimana pemahaman kognisi, emosi, motivasi, dan proses psikologis sejenis membentuk model proses budaya dan sosial. Setiap aliran dalam antropologi psikologis memiliki pendekatannya sendiri-sendiri.

Beberapa aliran dalam antropologi psikologis :

1. Antropologi psikoanalitis

2. Kebudayaan dan Kepribadian

3. Etnopsikologi

4. Antropologi kognitif

5. Antropologi psikiatris

\section{Manfaat Antropologi Hukum}

Pengertian Antropologi dapat dilihat dari 2 sisi yaitu Antropologi sebagai ilmu pengetahuan artinya bahwa Antropologi merupakan kumpulan pengetahuan- pengetahuan tentang kajian masyarakat dan kebudayaan yang disusun secarasistematis atas dasar pemikiran yang logis. Dan pengertian Antropologi yang kedua adalah cara-cara berpikir untuk mengungkapkan realitas sosial dan budaya yang ada dalam masyarakat dengan prosedur dan teori yang dapat dipertanggun jawabkan kebenarannya secara ilmiah. Manfaat Antropologi Hukum ada 4, antara lain :

\section{Manfaat bagi Teoritis}

Para teoritis yang dimaksud adalah ilmuan-ilmuan mahasiswa ilmu-ilmu socialterutama pada sarjana-sarjana ilmu hukum antropologi.Ilmu hukum yang lebih banyak mengabdikan diri kepada kepentingan memajukanilmu pengetahuan hokum, hukum yang termasuk dalam golongan ini adalah paratenagaten, staf peneliti ilmiah hukum, para dosen, asisten, staf pengajar, danmahasiswa yang lebih banyak berfikir dan berprilaku sebagai pengamat (toeschower) terhadap kehidupan umum ,beberapa manfaat teoritisnya yaitu: 
$>$ Dapat mengetahui pengertian-pengertian hukum yg berlaku dalam masyarakatsederhana dan modern.

$>$ Dapat mengetahui bagaimana masyarakat bisa mempertahankan nilai-nilai dasar yangdimiliki sekaligus mangetahui bagaimana masyarakat bisa melakukan perubahanperubahan terhadap nilai-nilai dasar tersebut.

$>$ Dapat mengetahui perbedaan-perbedaan pendapat atau pandangan masyarakat atau ssesuatu yang seharusnya mereka lakukan.

> Dapat mengetahui suku bangsa / masyarakat mana yang masih kuat/fanatik mempertahankan keberlakuan nilai-nilai budaya mereka.

\section{Manfaat bagi Praktis Hukum}

Praktisi hukum yang dimaksud adalah cendikiawan hukum diatas panggung arenahukum didalam kehidupan masyarakat termasuk dalam golongan ini seperti pembentuk hukum yaitu seperti DPR, pelaksana hukum seperti pejabat instansi pemerintah para penegak hukum yaitu : Polisi, Jaksa, Hakim, dan termasuk Pengacaraadvokasi.

\section{Manfaat bagi Praktisi Politik}

Dimaksudkan praktisi politik adalah aktivis politik yaitu semua yang dalam pikirandan perilakunya berperan dalam era politik baik yang duduk dalam pelaksanaan pemerintah (penyelenggara Negara) maupun yang berada diluar pemerintahan seperti berada diluar pemerintahan seperti berada lembaga-lembaga partai, organisasi politik dan lain-lain.

\section{Manfaat bagi Pergaulan Masyarakat}

Dimaksudkan dengan pergaulan didalam masyarakat adalah bahwa bumi ini bertambah kecil bukan saja radio dan televisi yang sudah sampai kepedesaan tetapi juga teleponmelalui jaringan hp yang sudah menjamur di pedesaan sehingga pembicaraan dalam jarak jauh sudah dapat dijangkau dalam waktu sesigkat mungkinini adalah semua kemajuan ilmu teknologi. 


\section{PENUTUP}

Antropologi adalah ilmu yang mempelajari manusia. Oleh karena itu antropologi didasarkan pada kemajuan yang telah dicapai ilmu pengetahuan sebelumnya. Pengertian Antropologi dapat dilihat dari 2 sisi yaitu Antropologi sebagai ilmu pengetahuan artinya bahwa Antropologi merupakan kumpulan pengetahuan- pengetahuan tentang kajian masyarakat dan kebudayaan yang disusun secarasistematis atas dasar pemikiran yang logis. Dan pengertian Antropologi yang kedua adalah cara-cara berpikir untuk mengungkapkan realitas sosial dan budaya yang ada dalam masyarakat dengan prosedur dan teori yang dapat dipertanggung jawabkan kebenarannya secara ilmiah. 


\section{DAFTAR PUSTAKA}

Darmini Roza dan Laurensius Arliman S, Peran Pemerintah Daerah Di Dalam Melindungi Hak Anak Di Indonesia, Masalah-Masalah Hukum, Volume 47, Nomor 1, 2018. https://doi.org/10.14710/mmh.47.1.2018.10-21

Laurensius Arliman S, Peranan Metodologi Penelitian Hukum di Dalam Perkembangan Ilmu Hukum di Indonesia, Soumatera Law Review, Volume 1, Nomor 1, 201. http://doi.org/10.22216/soumlaw.v1i1.3346.

Laurensius Arliman S, Peran Badan Permusyawaratan Desa di Dalam Pembangunan Desa dan Pengawasan Keuangan Desa, Padjadjaran Journal of Law, Volume 4, Nomor 3, 2017. https://doi.org/10.15408/jch.v4i2.3433.

Laurensius Arliman S, Penanaman Modal Asing Di Sumatera Barat Berdasarkan Undang- Undang Nomor 25 Tahun 2007 Tentang Penanaman Modal, Supremasi Hukum, Volume 1, Nomor 1, 2018. http://dx.doi.org/10.36441/hukum.v1i01.102 .

Laurensius Arliman S, Memperkuat Kearifan Lokal Untuk Menangkal Intoleransi UmatBeragama Di Indonesia, Ensiklopedia of Journal, Volume 1, Nomor 1, 2018, https://doi.org/10.33559/eoj.v1i1.18.

Laurensius Arliman S, Perkawinan Antar Negara Di Indonesia Berdasarkan Hukum Perdata Internasional, Kertha Patrika, Volume 39, Nomor 3, 2017, https://doi.org/10.24843/KP.2017.v39.i03.p03.

Laurensius Arliman S, Partisipasi Masyarakat Di Dalam Pengelolaan Uang Desa Pasca Undang-Undang Nomor 6 Tahun 2014 Tentang Desa, Jurnal Arena Hukum, Volume 12, Nomor 2, 2019, https://doi.org/10.21776/ub.arenahukum.2019.01202.5.

Laurensius Arliman S, Mewujudkan Penegakan Hukum Yang Baik Di Negara Hukum Indonesia, Dialogica Jurnalica, Volume 11, Nomor 1, 2019, https://doi.org/10.28932/di.v11i1.1831.

Laurensius Arliman S, Mediasi Melalui Pendekatan Mufakat Sebagai Lembaga Alternatif Penyelesaian Sengketa Untuk Mendukung Pembangunan Ekonomi Nasional, UIR Law Review, Volume 2, Nomor 2, 2018, https://doi.org/10.25299/uirlrev.2018.vol2(02).1587

Laurensius Arliman S, Peranan Filsafat Hukum Dalam Perlindungan Hak Anak Yang Berkelanjutan Sebagai Bagian Dari Hak Asasi Manusia, Doctrinal, Volume 1, Nomor 2,2016.

Laurensius Arliman S, Ni Putu Eka Dewi, Protection of Children and Women's Rights in Indonesia through International Regulation Ratification, Journal of Innovation, Creativity and Change Volume 15, Nomor 6, 2021.

Laurensius Arliman S, Gagalnya Perlindungan Anak Sebagai Salah Satu Bagian Dari Hak Asasi Manusia Oleh Orang Tua Ditinjau Dari Mazhab Utilitarianisme, Jurnal Yuridis, Volume 3, Nomor 2, 2016, http://dx.doi.org/10.35586/.v3i2.180.

Laurensius Arliman S, Tantangan Pendidikan Kewarganegaraan Pada Revolusi 4.0, Jurnal Ensiklopedia Sosial Review, Volume 2, Nomor 3, 2020.. 